\title{
Heritability of Growth Traits of Simmental Cattle in Balai Pembibitan Ternak Unggul- Hijauan Pakan Ternak (BPTU-HPT), Padang Mengatas, West Sumatra, Indonesia
}

\author{
Nilai Heritabilitas Sifat Produksi Sapi Simmental di Balai Pembibitan Ternak Unggul- \\ Hijauan Pakan Ternak (BPTU-HPT) Padang Mengatas, Limapuluh Kota, Sumatera Barat
}

\author{
D. E. Putra ${ }^{*}$, Sarbaini ${ }^{1}$, T. Afriani ${ }^{1}$, H. Suhada ${ }^{2}$, dan F. Arlina ${ }^{1}$ \\ ${ }^{1}$ Department of Genetics and Animal Breeding, Faculty of Animal Science Universitas Andalas Padang 25163, \\ 2 Department of Balai Pembibitan Ternak Unggul Hijauan Pakan Ternak, Padang Mengatas, Limapuluh \\ Kota District, West Sumatra \\ *E-mail: dinoekap@yahoo.com
}

(Diterima: 14 Agustus 2017; Disetujui: 26 September 2017)

\begin{abstract}
This study was done to determine the heritability of growth traits of Simmental cattle in BPTU-HPT Padang Mengatas, West Sumatra. Data were collected by observations and measurements of the cattle in the field, completed by the secondary data from BPTU-HPT recorded from 2010 to 2016. Data for heritability were collected from 455 offsprings belonged to 15 sires. Weight and body size are two parameters used to estimate the heritability and breeding value, the heritability was analyzed between weaning and yearling age and breeding value was only calculated for weaning age. The data were analyzed by using paternal halfsib correlation method. The heritability between bulls and offspring was varied in weaning age, ranged from 0.24 to 0.97 , and yearling age was showed high heritability in all parameters, ranged from 0.56 to 0.64 . The heritability of weaning weight was $0.50 \pm 0.19$, weaning body size (shoulder height, body length and heart girth) was $0.97 \pm 0.31 ; 0.24 \pm 0.13 ; 0.44 \pm 0.19$, yearling weight was $0.56 \pm 0.08$ and yearling body size was $0.58 \pm 0.08 ; 0.64 \pm 0.09$ and $0.56 \pm 0.08$ respectively. This result found that the highest heritability was shoulder height and the lowest heritability was body length. Relative breeding value above 0 represented by six sires with the highest breeding value was 37.12. Sires with the highest BV can be selected for future breeding in BPTU-HPT Padang Mengatas, while the lowest BV is recommended to be culled.
\end{abstract}

Keywords: heritability, Simmental cattle, weaning weight, yearling weight

\section{ABSTRAK}

Penelitian ini bertujuan untuk mengetahui keragaman genetik melalui estimasi nilai heritabilitas sifat pertumbuhan sapi potong yang dipelihara di BPTU-HPT Padang Mengatas, Sumatera Barat. Jenis data yang dikumpulkan meliputi data primer dan sekunder. Data primer diperoleh dari pengamatan dan pengukuran ternak di lapangan. Data sekunder berasal dari Balai pembibitan Ternak Unggul-Hijauan Pakan Ternak, Padang Mengatas, Sumatera Barat yang berupa data recording masing-masing ternak. Materi penelitian lapangan terdiri dari data rekording 2010 sampai 2016. Variabel yang diamati adalah nilai heritabilitas sifat pertumbuhan pada sapi Simmental. Data yang diperoleh dianalisis dengan estimasi nilai heritabilitas menggunakan metode korelasi saudara tiri sebapak. Catatan silsilah ditabulasi dari 455 ekor sapi Simmental siap sapih dari 15 ekor pejantan dan 455 ekor betina. Hasil penelitian menunjukan bahwa nilai heritabilitas berat sapih, ukuran tubuh sapih (tinggi pundak, panjang badan dan lingkar dada), berat satu tahun dan ukuran tubuh satu tahun secara berturut-turut adalah 0,50 0,$19 ; 0,97 \pm 0,31$;

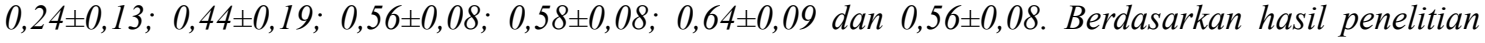
dapat disimpulkan bahwa nilai heritabilitas sapi Simmental di BPTU-HPT Padang mengatas tergolong tinggi.

Kata kunci: berat sapih, berat satu tahun, heritabilitas, sapi Simmental 


\section{INTRODUCTION}

In assisting meat supply the Balai Pembibitan Ternak Unggul dan Hijauan Pakan Ternak (BPTU-HPT) Padang Mengatas accelerates their cattle population, so as to produce superior and certified cattle. Breeding program which only focused for high genetic quality cattle is the most appropriate way to improve both quality and quantity. Breeding programs are primarily using character of body weight at different ages, this property is easily measured and positively correlated with other traits that have economic values and response to individual selection (Boligon et al., 2010). Selection of cattle withhigh genetic quality can be done by controlling marriage pattern, limiting the expenditure of livestock and improving the management of livestock raising so as to boost the productivity and population. The growth of beef cattle is related by their genetic traits, environmental factors and the interaction between the two. These factors lead to different performances from one location to another. Growth traits such as birth weight, weaning weight, yearling weight and body size are important economic properties on beef cattle production system. One of the properties that can be used as selection criteria is weaning weight, according to Hardjosubroto (1994) weaning weight is the weight at the time of calf separated/divided?? by the dam. It is obtained through weighing at the age of six to eight months or 205 days (Hardjosubroto, 1994). The weaning weights can be used to determine the ability of the mother milk production, the ability to care and also the child's genetic growth information.

Simmental cattle as one of genetic sources of livestock which has contributed greatlyin meat supply for the community must be improved, it can be done through selecting best genetic growth traits. The selection is aimed to produce superior Simmental cattle and which later improving meat availability for the national needs. Abovementioned, growth traits are one major component to determining best genetic information by using heritability approach which later can be used to calculate the breeding values of parents. Growth traits are can be calculated by estimating the genetic parameters of production traits (Warwick et al., 1990). The estimation of heritability value of cattle on the growth traits of several beef cattle was reported of many researchers in Indonesia (Duma, 1997; Suhada et al. , 2009; Putra et al., 2014).

Based on the above description, the information about the genetic potential of quantitative traits is very important in preparing the breeding program of livestock. Efforts to overcome these conditions it is necessary to know the basic data on the nature of cattle growth in BPTU-HPT Padang Mengatas so conducted to research on the estimated heritability value of Simmental cattle for growth traits in BPTU-HPT Padang Mengatas, West Sumatra Indonesia.

\section{METHODS}

This research was conducted from February until March 2017 BPTU-HPT Padang Mengatas, West Sumatera. Data were collected by observations and measurements of the cattle in the field, completed by the secondary data from BPTU-HPT recorded from 2010 to 2016. Data for heritability were collected from 455 offsprings belonged to 15 sires. These data include the pedigree, cattle performances, weaning weight, yearling weight, body size, weaning age, yearling age and the age of the dams. Weighing is done by using a scale of $1000 \mathrm{~kg}$ capacity. The weighing result is expressed in kilograms $(\mathrm{kg})$. Body length measurements were performed using a measuring stick and performed by measuring the distances of the shoulder blades and the furthest thigh (Anonimous, 2008). The measurement of the height of the shoulder is carried out with a measuring stick and is done by measuring the perpendicular distance from the ground to the peak of the shoulder behind the hump, and the measurement results expressed in centimeters $(\mathrm{cm})$ (Anonimous, 2008). Heart girth measurements were 
performed using a $200 \mathrm{~cm}$ measuring tape and performed by circling the chest through the 8th ribs behind the shoulder (Anonimous, 2008).

\section{Data Analysis}

Analysis of heritability values of weaning weight, yearling weight and body size using variance analysis paternal half west correlation method. The separation of the various components to estimate the value of heritability was done by a variety analysis using Completely Randomized Design OneWay Classification, with models (Warwick et al., 1990; Becker, 1992; and Hardjosubroto, 1994):

$$
\text { Yik }=\mu+\alpha i+\text { eik }
$$

where:

Yik $=$ observation on the kth individual on the sire i-th

$\mu=$ average population

$\alpha \mathrm{i}=$ effect of sire $\mathrm{i}$-th

eik $=$ deviations of the uncontrolled environmental and genetic effects on each individual

Weaning weight was corrected for weaning age of 120 days, sex and the age of dams based on Hardjosubroto (1994) as follows:

- Correction factor of sex:

$$
\mathrm{CF}_{\text {sex }}=\frac{\mathrm{WW} / \mathrm{YW}_{\mathrm{bull}}}{\mathrm{WW} / \mathrm{YW}_{\text {heifer }}}
$$

Where:

$\mathrm{CF}_{\text {sex }}=$ correction factor of sex

$\mathrm{WW} / \mathrm{YW}_{\text {bull }}=$ weaning weight and yearling weight of male cattle

$\mathrm{WW} / \mathrm{YW}_{\text {heifer }}=$ weaning weight and yearling weight of female cattle.

- Correction factor of dams age

$$
\mathrm{CF}_{\mathrm{damage}}=\frac{\mathrm{WW} / \mathrm{YW}_{\mathrm{s}}}{\mathrm{WW} / \mathrm{YW}_{\mathrm{a}}}
$$

Where:

$\mathrm{CF}_{\text {dam age }}=$ correction factor of dams age $\mathrm{WW} / \mathrm{YW}_{5}=$ the weight of the dam at 5 years
$\mathrm{WW} / \mathrm{YW}_{\mathrm{a}}=$ weaning weight at the actual age

Weaning Weight. Weaning weights were corrected for the weaning, sex age, and parental age according to the instructions (Hardjosubroto, 1994) as follows:

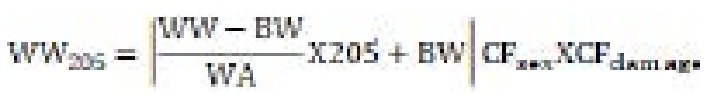

Where:

$\mathrm{WW}_{205}$ as corrected weaning weight at 205 days of age

WW $=$ actual weaning weight

$\mathrm{BW}=$ birth weight

$\mathrm{WA}=$ actual weaning age

Yearling Weight. The weight of a year is corrected to a weight of 365 days and sex of males (Hardjosubroto, 1994) as follows:

$$
\mathrm{YW}_{365}=\frac{\mathrm{YW}_{\mathrm{a}}-\mathrm{WW}_{\mathrm{a}}}{\mathrm{MA}} \times 365+\mathrm{WW}_{205}
$$

Where:

$\mathrm{YW}_{365}$ as corrected yearling weight at 365 days of age

$\mathrm{YWa}=$ actual yearling weight

$\mathrm{WWa}=$ actual weaning weight

$\mathrm{WW}_{205}=$ corrected weaning weight at 205 days of age

$\mathrm{MA}=$ No. of days between measure ages

Table 1. Analysis of variance for heritability

\begin{tabular}{lcccc}
\hline $\begin{array}{l}\text { Source of } \\
\text { variance }\end{array}$ & Df & SS & MS & EMS \\
\hline $\begin{array}{l}\text { Sire (s) } \\
\text { Heredity }\end{array}$ & $\mathrm{s}-1$ & $\mathrm{SS}_{\mathrm{s}}$ & $\mathrm{MS}_{\mathrm{s}}$ & $\boldsymbol{\sigma}_{\mathrm{w}}{ }^{2}+\mathrm{k \sigma}_{\mathrm{s}}{ }^{2}$ \\
in sire $(\omega)$ & $\mathrm{n} \cdot-1$ & $\mathrm{SS}_{\mathrm{w}}$ & $\mathrm{MS}_{\mathrm{w}}$ & $\boldsymbol{\sigma}_{\mathrm{w}}{ }^{2}$ \\
\hline
\end{tabular}

Total n-1

The value of $\mathrm{h} 2$ is calculated from the equation:

$$
\mathrm{h}^{2}=\frac{4 \sigma_{\mathrm{g}}^{2}}{\sigma_{\mathrm{v}}^{2}+\sigma_{\mathrm{w}}^{2}}
$$

Standard error estimates the value of heritability using the equation:

$$
S E h^{2}=\sqrt{4 \frac{2(1-t)^{2}[1+k-1 t]^{2}}{k(k-1)(s-1)}}
$$


Table 2. Mean and standard deviation of body size Simmental cattle in BPTU-HPT Padang Mengatas, West Sumatra.

\begin{tabular}{lcccccc}
\hline \multirow{2}{*}{ Variable } & \multicolumn{4}{c}{ Sex } & \multirow{2}{*}{ Average } & \multirow{2}{*}{$\mathrm{N}$} \\
\cline { 2 - 5 } & bull & $\mathrm{N}$ & heifer & $\mathrm{N}$ & & \\
\hline Weaning weight $(\mathrm{WW})(\mathrm{kg})$ & $197.11 \pm 45.73$ & 238 & $186.65 \pm 46.50$ & 217 & $192.03 \pm 46.40$ & 455 \\
Yearling Weight (YW) (kg) & $255.13 \pm 93.96$ & 119 & $237.22 \pm 71.83$ & 158 & $241.63 \pm 80.70$ & 277 \\
Weaning High Shoulder (WHS) (cm) & $103.94 \pm 6.30$ & 238 & $103.47 \pm 7.77$ & 217 & $103.71 \pm 7.06$ & 455 \\
Yearling High Shoulder (YHS) (cm) & $110.49 \pm 11.46$ & 119 & $110.03 \pm 8.33$ & 158 & $109.86 \pm 9.94$ & 277 \\
Weaning Body Length (WBL) (cm) & $108.28 \pm 10.40$ & 238 & $107.14 \pm 7.73$ & 217 & $107.72 \pm 9.22$ & 455 \\
Yearling Body Length (YBL) (cm) & $115.49 \pm 12.15$ & 119 & $114.10 \pm 9.74$ & 158 & $114.62 \pm 11.13$ & 277 \\
Weaning Heart Girth (WHG) (cm) & $130.48 \pm 13.02$ & 238 & $128.93 \pm 14.00$ & 217 & $129.73 \pm 13.53$ & 455 \\
Yearling Heart Girth (YHG) (cm) & $141.74 \pm 21.69$ & 119 & $138.56 \pm 15.33$ & 158 & $139.28 \pm 18.60$ & 277 \\
\hline
\end{tabular}

Where:

$\mathrm{s}=$ number of sire

$\omega=$ offspring in sire

$\mathrm{n}=$ total number of offspring

$\mathrm{ni}=$ the number of offspring in the sire $\mathrm{i}$-th

n. $=$ number of individuals

$\boldsymbol{\sigma}_{\mathrm{s}}^{2}=$ component of sire variance

$\boldsymbol{\sigma}_{\mathrm{w}}{ }^{2}=$ component of offspring variance

$\mathrm{k}=$ estimate middle value $\mathrm{n}_{\mathrm{i}}$

The estimate of breeding values (BV) according to Hardjosubroto (1994) is based on individual weight data in the population with the following equation:

Breeding value (relative):

$$
\mathrm{BV}=\frac{\mathrm{n} \cdot \mathrm{h}^{2}}{1+(\mathrm{n}-1) \mathrm{R}}(\overline{\mathrm{P}}-\overline{\mathrm{P}})
$$

Where:

$\mathrm{BV}=$ Breeding value

$\mathrm{h}^{2}=$ Heritability value

$\mathrm{R}=$ Repeatability value

$\overline{\mathrm{P}}=$ the average performance of sire

$\overline{\mathrm{P}}=$ average performance population

$\mathrm{n}=$ data total

\section{RESULTS AND DISCUSSION}

\section{Body Size Simmental Cattle}

The average body size of weaning weight and yearling weight, shoulder height, body length and heart girth of Simmental cattle in BPTU-HPT Padang Mengatas were presented in Table 2. The differences in weight and body size happened because the differences in the parent's age at given births and parity of offspring born and the sex of offspring. In another hand, environmental aspect also influenced the differences in weight and body size such as cattle health and feed supply are important because they have a direct effect on cattle performance, eg through food, disease, and management (Taylor, 1984; Pane, 1990).

\section{Heritability value}

Heritability of weaning ages and yearling ages using paternal half-sib correlation data was in high category (h2>0.3). Estimation of weaning ages and yearling ages Simmental cattle with 15 and 11 sires and 455 and 277 offspring respectively were presented in Table 3.

The result of the estimation analysis of heritability value weaning weight and yearling weight of Simmental cattle in BPTU-HPT Padang Mengatas may indicate that the diversity of weaning weight and yearling weight in a population of $50 \%$, $56 \%$ respectively, it was influenced by the additive genes and $50 \%, 44 \%$ respectively was influenced by environmental factors and nonadditive. This heritability belongs to the high category since it has a value $>$ 0.40 (Martojo, 1990). This high estimate of heritability is theoretically attributable to the increased genetic variation in the population. If the heritability increases, then this increase occurs because of the influence of increased genetic variation assuming constant environmental variation (Karnaen, 2008).

The estimation heritability of weaning weight and yearling weight of this research 
Table 3. Estimation heritability of Simmental cattle at weaning age and yearling age at BPTUHPT Padang Mengatas, West Sumatra

\begin{tabular}{lccc}
\hline Variable & $\begin{array}{c}\text { Total of } \\
\text { sire }\end{array}$ & $\begin{array}{c}\text { Total } \\
\text { offspring }\end{array}$ & $\begin{array}{c}\text { Heritability and } \\
\text { Standard Error }\end{array}$ \\
\hline Weaning weight $(\mathrm{WW})(\mathrm{kg})$ & 15 & 455 & $0.50 \pm 0.19$ \\
Yearling Weight $(\mathrm{YW})(\mathrm{kg})$ & 11 & 277 & $0.56 \pm 0.08$ \\
Weaning High Shoulder (WHS) $(\mathrm{cm})$ & 15 & 455 & $0.97 \pm 0.31$ \\
Yearling High Shoulder (YHS) $(\mathrm{cm})$ & 11 & 277 & $0.58 \pm 0.08$ \\
Weaning Body Length (WBL) $(\mathrm{cm})$ & 15 & 455 & $0.24 \pm 0.13$ \\
Yearling Body Length (YBL) $(\mathrm{cm})$ & 11 & 277 & $0.64 \pm 0.09$ \\
Weaning Heart Girth (WHG) $(\mathrm{cm})$ & 15 & 455 & $0.44 \pm 0.19$ \\
Yearling Heart Girth (YHG) $(\mathrm{cm})$ & 11 & 277 & $0.56 \pm 0.08$ \\
\hline
\end{tabular}

Table 4. Breeding value estimation of corrected weaning weight on Simmental cattle bulls at BPTU-HPT Padang Mengatas, West Sumatra

\begin{tabular}{clccc}
\hline Rank & Sire & $\mathrm{N}$ & Derived averages & BVr \\
\hline 1 & W. DROVIN & 65 & 229.15 & 37.12 \\
2 & W. DERMONT & 31 & 220.40 & 28.37 \\
3 & RED DENSITY & 26 & 219.72 & 27.69 \\
4 & AUKONIO RNC & 14 & 216.98 & 24.95 \\
5 & KS SUDANCE & 16 & 207.06 & 15.03 \\
6 & DOMINO & 9 & 200.26 & 8.23 \\
7 & LOUIS & 31 & 191.39 & -0.64 \\
8 & DAJARA & 15 & 189.35 & -2.68 \\
9 & CHAN BRAVO & 24 & 189.03 & -2.99 \\
10 & BRINKTON & 17 & 187.23 & -4.80 \\
11 & PFF EVRON & 13 & 186.26 & -5.78 \\
12 & LX MAYOR & 30 & 185.62 & -6.42 \\
13 & SG EVAN & 34 & 176.49 & -15.54 \\
14 & BBE & 58 & 176.08 & -15.95 \\
15 & E JOE & 72 & 153.94 & -38.09 \\
\hline
\end{tabular}

was higher than the heritability reported by Suhada et al. (2009) in the same cattle and place and the same maintenance management that was $0.39 \pm 0.16$ and $0.43 \pm 0.19$ as well as the heritability of beef cattle reported by Warwick et al. (1990) that is equal to 0.35 to 0.45 . The estimate of heritability value is also higher than the estimate of heritability performed by Sari et al. (2016); Son et al. (2014); Rastosari et al. (2014); Intaratham et al. (2012); Gunawan and Jakaria (2011) Khatab et al. (2009); Kurnianto (2009); Karnaen (2008); Van Nlekerk et al. (2006) and Wasike et al. (2006) but lower than the heritability that Said et al. (2016) and Kaswati et al. (2013). Lasley (1978) and Chapman (1985) suggest that the difference in heritability in each study is thought to be due to heritability, not a constant and dependent on population, estimated time and livestock used. A property with a low heritability needs to be enhanced by its genetics of breeding methods available if the selection is less effective or less efficient using other breeding methods (Martojo, 1990).

The estimated heritability of body size in this study differ from those reported by Baiduri et al. (2012) such as shoulder height, 
shoulder height one shoulder length, weaning body length, one-year body length, breastplate breasts, and chest circumference one year are $0.76 \pm 0.0014 ; 0.56 \pm 0.001 ; 0,92 \pm 0.0019$; $0.85 \pm 0.0015 ; 0.56 \pm 0.0013$ and $0.44 \pm$ 0.0009. Sari et al. (2016) reported estimates of heritability of body size such as shoulder height, shoulder height one shoulder length, weaning length, one-year body length, breast bush wings and one-year chest circumference were $0.216 \pm 0.357 ; 0.022 \pm 0.277 ; 0.320 \pm$ $0.395 ; 0.039 \pm 0.285 ; 0.295 \pm 0.385$ and 0.240 \pm 0.366 . Warwick et al. (1990) explain that environmental influences can lead to greater genetic expression and increase genetic diversity and estimation of heritability.

\section{Breeding Value of Weaning Weight}

Breeding value (BV) weaning weight in 15 (fifteen) Simmental cattle were presented in Table 4. In this study, there were 9 (nine) males with negative BV of weaned weights, mean weighing weight was below average population. Estimated breeding values (EBVs) is important to selecting animals for a range of traits that have direct impacts on productivity (Johnston et al., 2007). Weaning heritability value is used to calculate the breeding value of 15 (fifteen) Simmental cow's tail which is used as a male in BPTU-HPT Padang Mengatas.

The sire with the number W. DROVIN has the highest BV relative was 37.12 which means that the superiority of the W. DROVIN offspring is relatively $37.12 \mathrm{~kg}$ above the average of the population. According to Hardjosubroto (1994) if a livestock has a high BV then the livestock will have a high potential that can be inherited to the offspring. Several previous studies showed the higher BV in Kebumen Ongole Grade (KOG), Sumba Ongole (SO), Ongole crossbreed (PO) and Nalore cattle were $49.76 \mathrm{~kg}, 66.05$ $\mathrm{kg}, 45.96$ and $20.75 \mathrm{~kg}$ respectively (Sumadi et al ., 2017; Said et al., 2016; Paputungan et al., 2015; Rodriguez and Guerra, 2013). The magnitude of a male's performance can be estimated by breeding value (BV) so that cattle with high growth potential result in continuity of selection program. The five sires of Simmental cattle (W. Drovin, W. Dermont, Red Density, Aukonio RNC and KS Sudance) that can be recommended as the best sire Simmental cattle in BPTU-HPT Padang Mengatas. Furthermore, the sire with a lower BV can be culled in order to keep livestock productivity.

\section{CONCLUSION}

This result found that the highest heritability was shoulder height and the lowest heritability was body length. Relative breeding value above 0 represented by six sires with the highest breeding value was 37.12 . Sires with the highest BV can be selected for future breeding in BPTU-HPT Padang Mengatas, while the lowest $\mathrm{BV}$ is recommended to be culled.

\section{ACKNOWLEDGEMENTS}

Acknowledgments are sent to LPPM Universitas Andalas for research funding assistance in Beginner Lecturers Research Scheme in 2017, Head of Superior Livestock Breeding and Green Animal Feed (BPTUHPT) of Padang Mengatas who have given permission to conduct research and research data and Ms. Vivi Misriani, S.Pt who assist in collected data.

\section{REFFERENCES}

Anonimus. 2011. Indonesian standard Brahman cattle. Badan Standarisasi Nasional SNI 7651.1:2011.

Baiduri, A. A., Sumadi and N. Ngadiyono. 2012. Heritability estimation of body size at weaning age and first year of age on Bali cattle in Balai Pembibitan Ternak Unggul Sapi Bali, Jembrana, Bali. Buletin Peternakan. Vol. 36(1):14.

Becker, W. A. 1992. Manual of Quantitative Genetics. Fifth Edition. Academic 
Enterprises, Pullman, Washington. Boligon, A. A., F. Baldi and L. G. D. Albuquerque. 2011. Genetic parameters and relationship between growth traits and scrotal circumference measured at different ages in Nellore cattle. Genet. Mol. Biology 34(2):225-230.

Boligon, A. A., J. A. V. Silva, R. C. Sesana, J. C. Sesana, J. B. Junqueira and L. G. Albuquerque. 2010. Estimation of genetic parameters for body weight, scrotal circumference and testicular volume measured at different ages in nellore cattle. J AnimSci. 88:12151219.

Chapman, A. B. 1985. General and Quantitative Genetics. Department of Genetics, Meat and Animal Science, and Dairy Science. University of Wisconsin, Madison.

Duma, Y. 1997. Estimating multiple genetic parameters on Brahman cross and Ongole cattle in Ternak Bila River Ranch. Thesis. Graduate Program, Faculty of Animal Science, Universitas Gadjah Mada.

Falconer, D. S. and T. F. C. Mackay. 1996. Introduction to Quantitative Genetics. Fourth Edition. Longman Group Ltd., Malaysia.

Gunawan, A. and Jakaria. 2011. Genetic and non-genetic effect on birth, weaning and yearling weight in Bali cattle. Media Peternakan. Vol. 34(2): 93-98.

Hardjosubroto, W. 1994. Application of Livestock Breeding in the Field. PT Gramedia Widiasarana, Jakarta.

Intaratham, W., D. Kamkwan, Y. Laepaijit and E. Vitoonpong. 2012. Estimated Breeding Value and Genetic Trends of Growth Traits in Southern Indigenous Cattle from Multivariate Analysis. Proceedings of the 15th AAAP Animal Science Congress. Thammasat University, Rangsit Campus, Thailand.

Johnston, D. J., H. U. Graser and B. Tier. 2007. New developments in beef cattle genetic evaluation in Australia. Interbull Bull. 37:811.

Karnaen. 2008. Estimation of heritability, phenotypic correlation of body weight traits for Madura cattle. J.Indon.Trop. Anim.Agric. Vol. 33(3): 191-196.

Kaswati, Sumadi and N. Ngadiyono. 2013. The heritability estimation for birth weight, weaning weight and yearling weight for Bali cattle in Balai Pembibitan Ternak Unggul Sapi Bali. Buletin Peternakan. Vol. 37(2): 74-78.

Khattab, A.S., H. Grosu and A.M. Hussein. 2009. Estimation of genetic parameters and breeding values for lifetime production traits for Friesian cattle in Egypt. Archiva Zootechnica. 12(3):8286.

Kurnianto, E. 2009. Pemuliaan Ternak. Graha Ilmu, Yogyakarta.

Lasley, J. F. 1978. Genetics of Livestock Improvement 3rd edition., Prentice Hall Inc., Eaglewood Cliff, New Jersey.

Martojo, H. 1990. Peningkatan Mutu Genetik Ternak IUC Bank Dunia XVII. Dirjen Dikti dan IPB Bogor.

Pane, I. 1993. Pemuliabiakan Ternak Sapi. PT Gramedia Pustaka Utama. Jakarta, Indonesia.

Paputungan, U., L. Hakim, G. Ciptadi and H. F. N. Lapian. 2015. Selection response, breeding value and heritability of live weight in Ongole-Crossbred cows. Int. J. Agri. Sci. Nat. Res. 2(1): 6-13.

Putra, W. P. B., Sumadi and T. Hartatik. 2014. The estimation of breeding value and most probable producing ability of production traits Aceh cattle at Indrapuri District Aceh Province. Buletin Peternakan Vol. 38 (1): 1-7.

Rastosari, A., Sumadi and T. Hartatik. 2014. Estimation breeding value for Brahman cattle in BPTU-HPT Sembawa, South Sumatra. Proceeding Seminar Nasional Biodiversitas V, Surabaya 6 September 2014. Hal: 250-253. 
Rodriguez, Y. and D. Guerra. 2013. Evidence of genotype-environment interaction for final live weight in the performance test of the Cuban Zebu. Cuban. J. Agric. Sci. 47(1):1317.

Said, S., P. P. Agung, W. P. B. Putra, S. Anwar, A. S. Wulandari and A. Sudiro. 2016. Selection of Sumba Ongole (SO) cattle based on breeding value and performance test. J. Indonesian Trop. Anim. Agric, Vol. 41 (2): 175-187.

Sari, E. M., M. A. Nahsir and C. Hasnani. 2016. Heritability estimation of quantitative traits in Aceh cattle. Agripet: Vol. 16(1):37-41

Suhada, H., Sumadi and N. Ngadiyono. 2009. Estimation of genetic parameters of production characteristics on Simmental cattle at Balai Pembibitan Ternak Unggul Sapi Potong Padang Mengatas, Sumatera Barat. Buletin Peternakan: Vol.33(1): 1-7.

Sumadi, A. Fatoni, D. Maharani, N. Ngadiyono, D.T. Widayati, C.T. Noviandi and M. Khusnudin. 2017.
Breeding value of based on offspring weaning weight as a recommendation for selection Kebumen Ongole Grade cattle. J. Indonesian Trop. Anim. Agric. Vol. 40(3): 160-166.

Taylor, R. E. 1984. Beef Production and The Beef Industry. Macmillan Publishing Company, New York.

Van Niekerk, M. V. and Neser, F. W. C. 2006. Genetic Parameters for Growth Traits in South African Limousin cattle. South African Journal of Animal Science 2006 (36): 6-9.

Warwick, E. J., J. M. Astuti and W. Hardjosubroto. 1990. Pemuliaan Ternak. Universitas Gadjah Mada Press, Yogyakarta.

Wasike, C. B., E. D. Ilatsia, J. M. K. Ojango and A. K. Kahi. 2006. Genetic Parameters for Weaning Weight of Kenyan Boran Cattle Accounting for Direct-Maternal Genetic Covariances. South African Journal of Animal Science 2006 (36):275-281. 